\title{
Research автісік: Effect of growth regulator and chemicals on leaf nutrient status in Tamarind plantation at Dharmapuri district of Tamil Nadu
}

Article Chronicle:

Received :

12.07.2017;

Accepted :

25.07.2017

KeY WoRds:

Tamarind leaves, Growth regulator, Chemicals, Nutrient status, Total nitrogen, Fruit yield

\section{C.N. HARI PRASATH, A.BALASUBRAMANIAN, S.RADHAKRISHNAN AND A.MAYAVEL}

SUMMARY : In order to assess the influence of growth regulators and chemicals on leaf nutrient status of tamarind in 15 year old plantation was treated with different combination of growth regulators and chemicals through foliar application. The treatments namely $\mathrm{ZnSO}_{4} 0.5$ per cent + Boric acid 0.3 per cent, Planofix, Paclobutrazol and Ethephon were applied in tamarind plantation at Chinnakupam village, Harur taluk, Dharmapuri district, Tamil Nadu. Nutritional status of tamarind leaves were significantly improved by the application of growth regulators and chemicals. The total nitrogen $(3.72 \%$ and 3.14 $\%)$, total phosphorus $(0.345 \%$ and $0.338 \%)$ total potassium $(0.203 \%$ and $0.191 \%)$ were recorded maximum by the foliar application of Paclobutrazol and Planofix. The lowest nutrient status (Total nitrogen $-1.90 \%$, total phosphorus $-0.184 \%$ and total potassium $-0.119 \%$ ) was observed in control (no floreign application). To conclude the study, the Paclobutrazol and Planofix in tamarind tree enhanced the nutrient status in the tamarind leaves and hence it can contribute to fruit yield in tamarind plantations.

How to cite this article : Prasath, C.N.Hari, Balasubramanian, A., Radhakrishnan, S. and Mayavel, A. (2017). Effect of growth regulator and chemicals on leaf nutrient status in Tamarind plantation at Dharmapuri district of Tamil Nadu. Agric. Update, 12(TECHSEAR-2) : 520-523; DOI: 10.15740/HAS/AU/12.TECHSEAR(2)2017/ 520-523.
Author for correspondence :

\section{C.N. HARI PRASATH}

Department of

Silviculture, Forest

College and Research

Institute,

METTUPALAYAM

(T.N.) INDIA

Email: prasathforestry

$@$ gmail.com

See end of the article for authors' affiliations 